\title{
Epidemiology of HBoV1 infection and relationship with meteorological conditions in hospitalized pediatric patients with acute respiratory illness: a 7-year study in a subtropical region
}

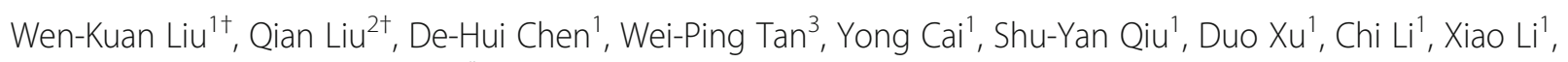
Zheng-Shi Lin ${ }^{1}$ and Rong Zhou ${ }^{* *}$

\begin{abstract}
Background: Human bocavirus 1 (HBoV1) is an important cause of acute respiratory illness (ARI), yet the epidemiology and effect of meteorological conditions on infection is not fully understood. To investigate the distribution of HBoV1 and determine the effect of meteorological conditions, hospitalized pediatric patients were studied in a subtropical region of China.

Methods: Samples from 11,399 hospitalized pediatric patients ( $\leq 14$ years old), with ARI were tested for HBoV1 and other common respiratory pathogens using real-time PCR, between July 2009 and June 2016. In addition, local meteorological data were collected.

Results: Of the 11,399 patients tested, 5606 (49.2\%) were positive for at least one respiratory pathogen. Two hundred forty-eight of 11,399 (2.2\%) were positive for HBoV1 infection. Co-infection was common in HBoV1-positive patients $(45.2 \%, 112 / 248)$. A significant difference in the prevalence of HBoV1 was found in patients in different age groups ( $p<0.001)$, and the peak prevalence was found in patients aged 7-12 months (4.7\%, 56/1203). Two HBoV1 prevalence peaks were found in summer (between June and September) and winter (between November and December). The prevalence of HBoV1 was significantly positively correlated with mean temperature and negatively correlated with mean relative humidity, and the mean temperature in the preceding month had better explanatory power than the current monthly temperature.
\end{abstract}

Conclusions: This study provides a better understanding of the characteristics of HBoV1 infection in children in subtropical regions. Data from this study provide useful information for the future control and prevention of HBoV1 infections.

Keywords: Human bocavirus 1, Acute respiratory illness, Epidemiology, Meteorological conditions

\footnotetext{
* Correspondence: zhourong@gird.cn

${ }^{+}$Wen-Kuan Liu and Qian Liu contributed equally to this work.

${ }^{1}$ State Key Laboratory of Respiratory Diseases, National Clinical Research

Center for Respiratory Disease, The First Affiliated Hospital of Guangzhou

Medical University, Guangzhou Institute of Respiratory Health, Guangzhou

Medical University, Guangzhou, China

Full list of author information is available at the end of the article
}

(c) The Author(s). 2018 Open Access This article is distributed under the terms of the Creative Commons Attribution 4.0 International License (http://creativecommons.org/licenses/by/4.0/), which permits unrestricted use, distribution, and reproduction in any medium, provided you give appropriate credit to the original author(s) and the source, provide a link to the Creative Commons license, and indicate if changes were made. The Creative Commons Public Domain Dedication waiver (http://creativecommons.org/publicdomain/zero/1.0/) applies to the data made available in this article, unless otherwise stated. 


\section{Background}

Human bocavirus 1 (HBoV1), which belongs to family Parvoviridae, was firstly identified in respiratory secretions of children with respiratory tract disease in 2005 $[1,2]$. HBoV1 has been confirmed as an important respiratory pathogen and is found in respiratory infections in children and adults worldwide. The prevalence of HBoV1 nucleic acid detection varies from 1.5 to $33 \%$ in patients with acute respiratory illness (ARI), according to different studies [3-7]. Serological and nucleic acid test results are generally consistent [8-11], showing HBoV1 infection is very common. HBoV1 can cause both upper respiratory illness (URI) and lower respiratory illness (LRI) [12-18]. Infection with HBoV1 can lead to development of a cough, rhinitis, fever and other common clinical symptoms $[15,19]$. In some cases, it can cause respiratory distress, hypoxia, wheezing and other severe respiratory symptoms $[18,20]$. Clinical diagnosis is mainly pneumonia, bronchitis, pneumothorax, mediastinal emphysema and otitis media and other complications [18-22]. In some cases, patients develop severe respiratory injury symptoms, which can be fatal [21, 23]. HBoV1 can be detected in fecal samples [24], blood samples [25, 26], urine [27, 28], cerebrospinal fluid [29-31], river water [32] and sewage [33, 34], indicating that HBoV1 may be associate with a variety of diseases. Current in vitro studies modeling tissue-like airway epithelial cells cultures show HBoV1 infection can lead to disruption of the tight-junction barrier, loss of cilia and epithelial cell hypertrophy [35-37], similar to lung injury tissue changes in vivo. There is currently no vaccine or specific treatment for this virus; prevention and treatment of $\mathrm{HBoV1}$-related diseases still require further research. The prevalence of respiratory viruses is associated with many factors, including local climate, which may impact the survival and spread of the viruses [38]. Studying the epidemiology of HBoV1 and its relationship with meteorological conditions will improve diagnosis, treatment, control and prevention of this virus.

In this study, we investigated the epidemiology of HBoV1 infection in children ( $\leq 14$ years old) hospitalized with ARI in a subtropical region in China over a 7-year period. In addition, we collected climate data to determine if there was a relationship between $\mathrm{HBoV} 1$ prevalence and meteorological conditions. This study will add to existing epidemiological data on HBoV1 and its relationship with climate conditions in subtropical regions and will play a positive role in HBoV1 control and prevention.

\section{Methods}

Respiratory sample and meteorological data collection The study sites were three tertiary hospitals in Guangzhou, southern China (Longitude: E112 ${ }^{\circ} 57^{\prime}$ to E114 03'; Latitude $\mathrm{N} 22^{\circ} 26^{\prime}$ to $\mathrm{N} 23^{\circ} 56^{\prime}$ ). Inclusion criteria were pediatric patients $(\leq 14$ years old) who presented with at least two of the following symptoms: cough, pharyngeal discomfort, nasal obstruction, rhinitis, dyspnea or who were diagnosed with pneumonia by chest radiography during the previous week. Chest radiography was conducted according to the clinical situation of the patient. Throat swab samples were collected from the enrolled patients between July 2009 and June 2016 for routine screening for respiratory viruses, Mycoplasma pneumoniae (MP), and Chlamydophila pneumoniae $(\mathrm{CP})$. The samples were refrigerated at $2-8{ }^{\circ} \mathrm{C}$ in viral transport medium, transported on ice and analyzed immediately or stored at $-80{ }^{\circ} \mathrm{C}$ before analysis, as described previously [15, 39].

Meteorological data for Guangzhou, were collected from July 2009 to June 2016, from the China Meteorological Administration, including the monthly mean temperature $\left({ }^{\circ} \mathrm{C}\right)$, mean relative humidity $(\%)$, rainfall $(\mathrm{mm})$, mean wind speed $(\mathrm{m} / \mathrm{s})$, mean air pressure $(\mathrm{hPa})$, mean vapor pressure (hPa), sunshine duration (h).

\section{Real-time PCR for HBoV1 and common respiratory pathogen detection}

DNA and RNA were extracted from the respiratory samples using the QIAamp DNA Mini Kit and QIAamp Viral RNA Mini Kit (Qiagen, Shanghai, China), respectively, in accordance with the manufacturer's protocols. Taqman real-time PCR for HBoV1 was designed based on the conserved region of the NP1 gene, as described previously [15]. Common respiratory pathogens, including respiratory syncytial virus (RSV), influenza A virus (InfA), influenza B virus (InfB), four types of parainfluenza (PIV1-4), adenovirus (ADV), enterovirus (EV), human metapneumovirus (HMPV), four strains of human coronavirus (HCoV-229E, OC43, NL63 and HKU1), human rhinovirus (HRV), MP and CP were detected simultaneously as previously reported [40].

\section{Statistical analysis}

Data were analyzed using Chi-squared test and Fisher's exact test in SPSS 19.0 (SPSS Inc., Chicago, IL, USA). Correlation with climate data was analyzed using multiple linear regression analysis. All tests were two-tailed and a $p$ value $<0.05$ was considered as statistically significant.

\section{Results}

\section{Patients and HBoV1 distribution}

Eleven thousand three hundred ninety-nine pediatric patients ( $\leq 14$ years old) hospitalized with ARI were enrolled in the study between July 2009 and June 2016. The male-to-female ratio was 1.82:1 (7361:4038) and the median age was 1.75 years (interquartile range $0.75-3.83)$. Overall, $86.5 \%$ (9857/11399) of patients were under the age of 5 years. All the 11,399 
patients were tested for all 18 pathogens mentioned, and $5606(49.2 \%)$ were positive for one or more of those pathogens (Table 1), and had a median age of 1.50 years (interquartile range 0.67-3.00). The male-to-female ratioes were 1.94: 1 (3698:1908) in pathogen-positive patients and 1.72: 1 (3663:2130) in pathogen-negative patients $(p=0.002)$.

Two hundred forty-eight of 11,399 patients (2.2\%) tested positive for HBoV1 infection. Of the HBoV1-positive patients, 112 (45.2\%) were co-infected with other pathogens, most frequently with RSV (11.7\%, 29/248) (Table 1). The median age was 1 year (interquartile range 0.75-1.83). The male-to-female ratio was 2.54:1 (178:70) in HBoV1-positive patients and 1.81:1 (7183:3968) in HBoV1-negative patients $(p=0.019)$.

\section{Age distribution of HBoV1-positive patients}

To clarify the age distribution of HBoV1, patients were divided into seven age groups; 0-3 months, 46 months, 7-12 months, 1-2 years, 3-5 years, 610 years and 11-14 years old. There was a significant difference in the prevalence of HBoV1 in patients in different age groups $(p<0.001)$ and the peak prevalence was found in patients aged 7-12 months (4.7\%, 56/1203) (Fig. 1).

\section{Seasonal distribution of HBoV1}

In this study, we monitored the prevalence of HBoV1 in patients ( $\leq 14$ years old) hospitalized with ARI from July 2009 and June 2016. Overall, there were two main prevalence peaks in each year. The large peaks of the epidemic were between June and September of each year, including September 2009 (12.8\%, 20/156), June 2010 (12.3\%, 10/ 81), June 2011 (9.6\%, 10/104), August 2012 (7.0\%, 10/142), August 2013 (4.8\%, 10/208) and September 2014 (3.4\%, 5/ 148). The small prevalence peaks were between November and December of each year, including December 2009 (4.6\%, 5/108), December 2010 (3.0\%, 3/101), December 2011 (5.3\%, 7/132), November 2012 (3.1\%, 5/160) and December 2013 (1.5\%, 3/200). Conversely, in 2015 the large and small prevalence peaks were November 2015 (5.8\%, $7 / 121)$ and July $(3.4 \%, 4 / 119)$, respectively. There was no obvious cut off between the large and small prevalence peaks in 2014 (Fig. 2). The same temporal distribution was observed between the monthly distribution of $\mathrm{HBoV} 1$ and proportion of positive samples (Fig. 2).

Table 1 Distribution of respiratory pathogens in 11,399 pediatric patients hospitalized with acute respiratory illness

\begin{tabular}{|c|c|c|c|c|c|c|c|c|c|c|c|c|c|c|c|c|c|c|c|}
\hline Pathogen & HBoV1 & $\inf A$ & $\operatorname{infB}$ & RSV & EV & $\mathrm{HRV}^{\mathrm{a}}$ & ADV & PIV1 & PIV2 & PIV3 & PIV4 & $229 \mathrm{E}$ & OC43 & NL63 & HKU1 & HMPV & MP & $\mathrm{CP}$ & Positive rate, $\%$ \\
\hline$\overline{\mathrm{HBOV} 1}$ & 248 & 13 & 4 & 29 & 15 & 17 & 14 & 4 & 3 & 10 & 1 & 0 & 9 & 3 & 1 & 7 & 14 & 0 & 2.2 \\
\hline $\inf A$ & & 839 & 34 & 95 & 41 & 8 & 23 & 9 & 7 & 11 & 0 & 7 & 38 & 4 & 4 & 12 & 46 & 1 & 7.4 \\
\hline $\operatorname{infB}$ & & & 300 & 25 & 9 & 6 & 4 & 1 & 1 & 6 & 0 & 0 & 9 & 0 & 1 & 5 & 15 & 2 & 2.6 \\
\hline RSV & & & & 1690 & 73 & 45 & 38 & 9 & 13 & 14 & 3 & 10 & 29 & 10 & 3 & 16 & 38 & 8 & 14.8 \\
\hline EV & & & & & 498 & 16 & 24 & 14 & 2 & 13 & 1 & 4 & 10 & 6 & 1 & 10 & 21 & 5 & 4.4 \\
\hline $\mathrm{HRV}^{\mathrm{a}}$ & & & & & & 402 & 14 & 3 & 2 & 12 & 2 & 2 & 11 & 1 & 1 & 3 & 21 & 6 & 5.0 \\
\hline ADV & & & & & & & 621 & 5 & 3 & 7 & 2 & 3 & 14 & 5 & 2 & 9 & 36 & 3 & 5.4 \\
\hline PIV1 & & & & & & & & 116 & 2 & 2 & 0 & 2 & 5 & 1 & 0 & 1 & 9 & 0 & 1.0 \\
\hline PIV2 & & & & & & & & & 72 & 3 & 0 & 2 & 9 & 0 & 0 & 2 & 3 & 0 & 0.6 \\
\hline PIV3 & & & & & & & & & & 296 & 0 & 1 & 15 & 1 & 1 & 3 & 15 & 1 & 2.6 \\
\hline PIV4 & & & & & & & & & & & 25 & 1 & 1 & 0 & 0 & 0 & 3 & 0 & 0.2 \\
\hline $229 E$ & & & & & & & & & & & & 64 & 14 & 2 & 0 & 3 & 3 & 0 & 0.6 \\
\hline OC43 & & & & & & & & & & & & & 346 & 2 & 1 & 14 & 27 & 3 & 3.0 \\
\hline NL63 & & & & & & & & & & & & & & 60 & 1 & 1 & 3 & 1 & 0.5 \\
\hline HKU1 & & & & & & & & & & & & & & & 38 & 1 & 3 & 1 & 0.3 \\
\hline HMP & & & & & & & & & & & & & & & & 321 & 9 & 0 & 2.8 \\
\hline MP & & & & & & & & & & & & & & & & & 760 & 2 & 6.7 \\
\hline $\mathrm{CP}$ & & & & & & & & & & & & & & & & & & 77 & 0.7 \\
\hline Single infection & 136 & 546 & 203 & 1314 & 286 & 261 & 458 & 67 & 35 & 203 & 13 & 26 & 185 & 28 & 19 & 243 & 531 & 51 & 40.4 \\
\hline Co-infection & 112 & 293 & 97 & 376 & 212 & 141 & 163 & 49 & 37 & 93 & 12 & 38 & 161 & 32 & 19 & 78 & 229 & 26 & 8.8 \\
\hline
\end{tabular}

Data are number in each group, except where specifically stated. HBoV1 human bocavirus 1 , InfA influenza A virus, InfB influenza B virus, RSV respiratory syncytial virus, EV enterovirus, HRV human rhinovirus, PIV1-4 parainfluenza 1-4, ADV adenovirus, HMPV human metapneumovirus, $229 E$ human coronavirus $229 \mathrm{E}$, OC43 human coronavirus OC43, NL63 human coronavirus NL63, HKU1 human coronavirus HKU1, MP Mycoplasma pneumoniae, CP Chlamydophila pneumoniae. ${ }^{a}$ HRV was detected since January 2012, and a total of 8084 cases were collected 


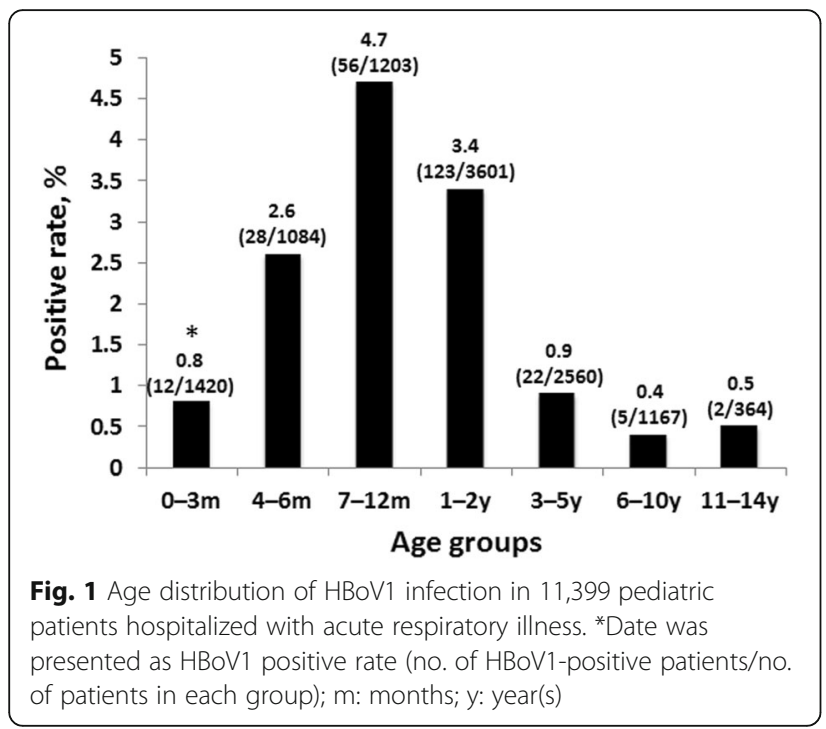

\section{Correlation between HBoV1 epidemics and meteorological conditions}

We collected meteorological data for Guangzhou, including monthly mean temperature, mean relative humidity, rainfall, mean wind speed, mean air pressure, mean vapor pressure and sunshine duration for a 7-year period, to explore the correlation between meteorological conditions and prevalence of HBoV1.

Guangzhou, which is located in southern China (longitude $112^{\circ} 57^{\prime}$ to $114^{\circ} 3^{\prime}$, latitude $22^{\circ} 26^{\prime}$ to $23^{\circ} 56^{\prime}$ ), has a maritime subtropical monsoon climate. Between July 2009 and June 2016, the mean temperature was $21.8 \pm 5.8^{\circ} \mathrm{C}$ (mean \pm standard deviation), humidity was $77.2 \pm 7.3 \%$, sunshine duration was $132.7 \pm 59.5 \mathrm{~h}$, wind speed was $2.2 \pm 0.6 \mathrm{~m} / \mathrm{s}$, rainfall was $175.2 \pm 165.9 \mathrm{~mm}$, air pressure was $1005.6 \pm 6.0 \mathrm{hPa}$ and vapor pressure was $21.3 \mathrm{~h} \pm 7.4 \mathrm{hPa}$. Between 2009 and 2016, the mean temperature from May to September was greater than $25^{\circ} \mathrm{C}$ (Fig. 3).

For multiple linear regression analysis of $\mathrm{HBoV} 1$ prevalence and meteorological conditions correlation, independent variables of mean air pressure (adjusted $\mathrm{R}^{2}=0.793, p<0.001$ ) and mean vapor pressure (adjusted $\left.\mathrm{R}^{2}=0.929, p<0.001\right)$, which linearly associated with mean temperature, and rainfall (adjusted $\mathrm{R}^{2}=0.278, p<0.001$ ), which strongly correlated with mean relative humidity, were excluded. The independent variables for the final multiple linear regression analysis included mean temperature, mean relative humidity, mean wind speed and sunshine hours. The effect of temperature had a delay therefore mean temperature in the preceding month (mean temperature 1 month before) was also included as an independent variable in the analysis (Table 2). Both regression models were established $(p<0.001)$ and the adjusted $R^{2}$ values were 0.373 and 0.231 in the mean temperature in the preceding month model and the current monthly temperature model, respectively. HBoV1 prevalence was positively correlated with temperature (coefficient $=0.259$ in the current temperature model $(p=0.002)$, coefficient $=0.328$ in mean temperature in the preceding month model $(p<0.001))$. Conversely, HBoV1 prevalence was negatively correlated with relative humidity (coefficient $=-0.126$ in the current temperature model $(p=0.024)$, coefficient $=-0.083$ in the temperature delay model $(p=0.039))$ (Table 2$)$.

\section{Discussion}

ARI is one of the most common human diseases, predominantly caused by different respiratory viruses [41, 42]. One of these viruses, HBoV1 infection, causes global epidemics, has a high public health burden and circulates with different patterns in different areas [3-7, 43]. In general, the prevalence of viruses varies because of factors such as

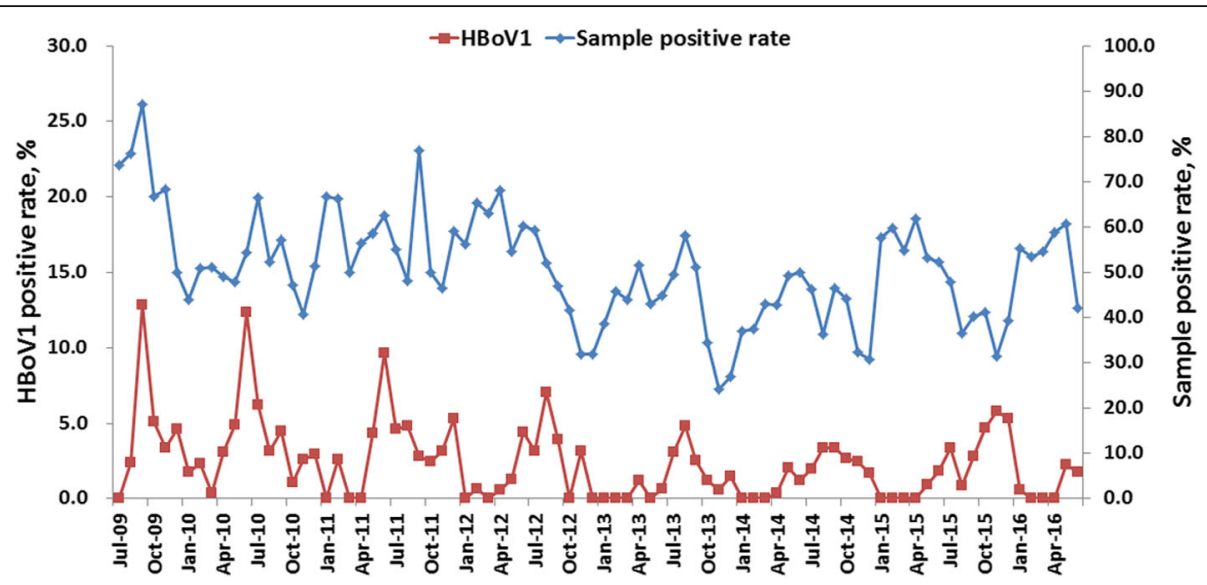

Fig. 2 Seasonal distribution of HBoV1 infection in pediatric patients hospitalized with acute respiratory illness from July 2009 to June 2016 

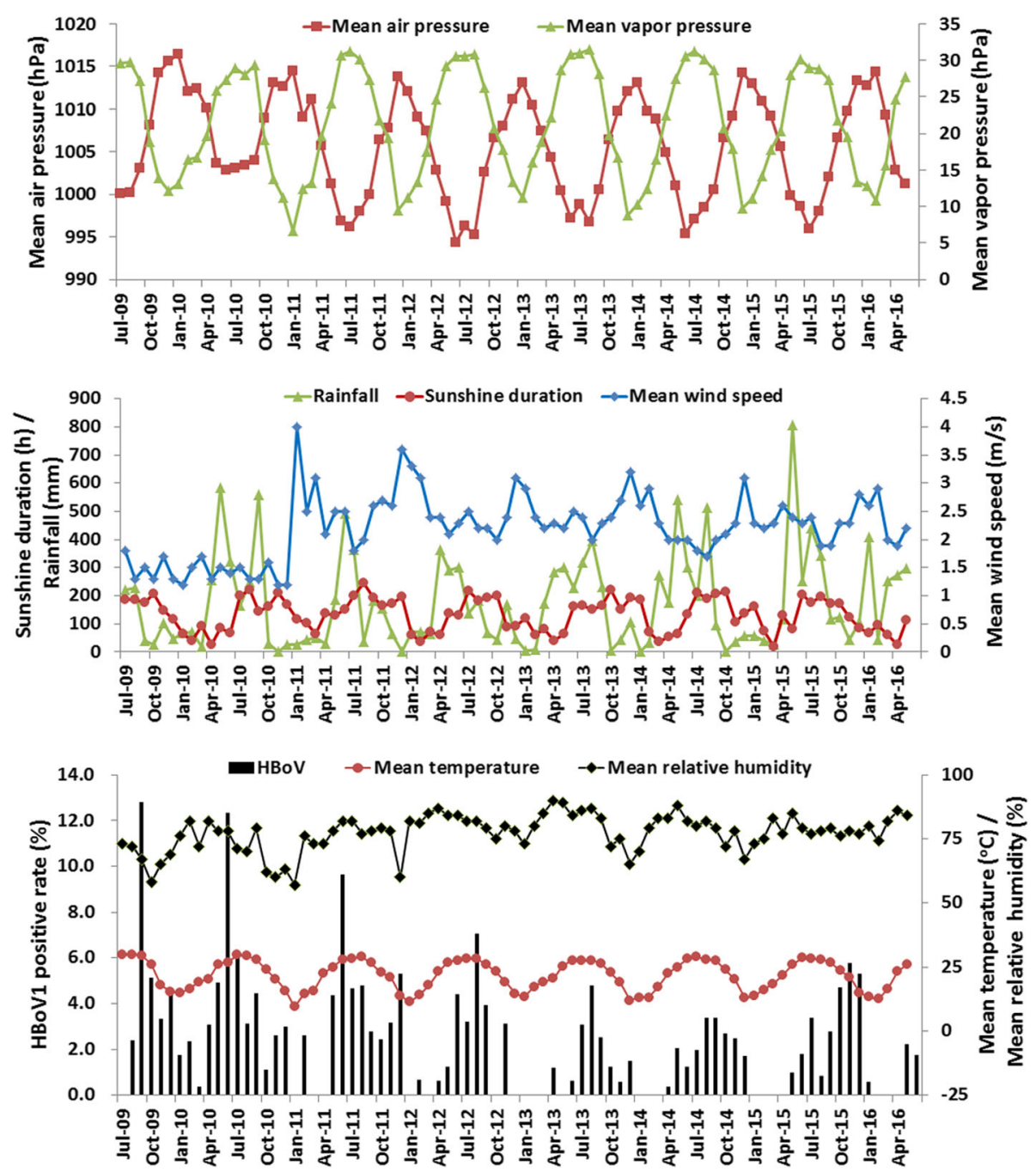

Fig. 3 Monthly distribution of HBoV1 and meteorological factors in Guangzhou from July 2009 to June 2016

Table 2 Multiple linear regression analysis of the correlation between HBoV1 prevalence and meteorological factors in Guangzhou from July 2009 to June 2016

\begin{tabular}{lll}
\hline Meteorological factors & Correlation coefficient & $p$ value \\
\hline Mean temperature $\left({ }^{\circ} \mathrm{C}\right)$ & $\mathbf{0 . 2 5 9}$ & $\mathbf{0 . 0 0 2}$ \\
Mean relative humidity $(\%)$ & $\mathbf{- 0 . 1 2 6}$ & $\mathbf{0 . 0 2 4}$ \\
Mean wind speed $(\mathrm{m} / \mathrm{s})$ & -0.190 & 0.736 \\
Sunshine duration $(\mathrm{h})$ & -0.006 & 0.426 \\
The regression model adjusted $\mathrm{R}^{2}=0.231, p<0.001$ & & $\mathbf{<}$ \\
Mean temperature in the preceding month $\left({ }^{\circ} \mathrm{C}\right)$ & $\mathbf{0 . 3 2 8}$ & $\mathbf{0 . 0 0 1}$ \\
Mean relative humidity $(\%)$ & $\mathbf{- 0 . 0 8 3}$ & $\mathbf{0 . 0 3 9}$ \\
Mean wind speed $(\mathrm{m} / \mathrm{s})$ & -0.453 & 0.317 \\
Sunshine duration $(\mathrm{h})$ & -0.014 & 0.051 \\
\hline
\end{tabular}

Multiple linear regression analysis was performed using HBoV1 monthly prevalence as the dependent variable, monthly mean temperature (or mean temperature in the preceding month), mean relative humidity, mean wind speed and sunshine duration as the independent variables

Data captured in bold are highly significant 
geographical location, climatic conditions, population and social activity [38]. Epidemiology of HBoV1 in temperate regions has been described in more detail and a high incidence of infection has been observed in children under the age of 2 years in winter and spring [15, 16, 39, 44].

To describe the epidemiology of HBoV1 in Guangzhou, we collected throat swabs from 11,399 children ( $\leq 14$ years old), hospitalized with ARI and monitored HBoV1 and other common respiratory pathogens over a 7-year period (Table 1).

In the current study, 86.5\% (9857/11399) of patients were under the age of 5 years, with a median age of 1.75 years, indicating that infants and young children were most at risk of ARI, consistent with previous reports [45, 46]. Overall, 49.2\% (5606/11399) of patients tested positive for one or more respiratory pathogens, $2.2 \%$ (248/11399) of patients were tested with HBoV1 infection (Table 1). A higher prevalence of HBoV1 was detected in male patients compared with female patients $(p=0.019)$, consistent with previous reports $[15,16,39,44]$.

Co-infection with HBoV1 and other pathogens is common [14, 15]. In our study, $45.2 \%(112 / 248)$ of HBoV1-positive patients also tested positive for other pathogens (Table 1). This may be partly caused by coinciding epidemics of HBoV1 and other pathogens. In our study, the HBoV1 seasonal distribution and total positive pathogen distribution were consistent, confirming this inference (Fig. 2). Current research shows that HBoV1 infection can lead to the collapse of the first line of defense of airway epithelium [35-37], which may lead to a higher susceptibility to other pathogens, explaining the high rate of co-infection. Whether co-infection leads to more severe disease is currently unknown and more research is needed to determine this. The characteristics of the HBoV1 infection are likely to be a good model for studying the effects of co-infections.

In this study, there was a significant difference in prevalence of HBoV1 in patients of different ages $(p<0.001)$. The majority of HBoV1 infections occurred in patients under 2 years old and the peak frequency of HBoV1 infection occurred in patients aged 7-12 months (Fig. 1), consistent with previous serological and epidemiological reports on the virus $[8-11,15,16,39,44]$. This might be because children's immune systems are still under development and maternal antibodies gradually disappear in this age group. The distribution of HBoV1 in patients of different ages will provide important reference for future vaccines and new drug research and development, as well as providing important data for disease prevention and control.

Many factors affect the epidemiology of pathogens, such as geographical location and local climate. Guangzhou, a central city and main transport hub in southern China, is located in a subtropical region.
Guangzhou is hot and has high annual rainfall, long summers, short winters and the annual precipitation and high temperature are almost in the same period (Fig. 3). In this study, two HBoV1 peaks were observed (Fig. 2). The large prevalence peaks of HBoV1 infection occurred between June and September of each year, which are the summer months in Guangzhou, with mean temperatures of higher than $25^{\circ} \mathrm{C}$ (Fig. 3). Small peaks of HBoV1 infection occurred in winter, between November and December of each year. This seasonal distribution is similar to the prevalence in subtropical regions reported previously [47], but different from the HBoV1 epidemics in temperate regions, which mostly occur in winter and spring $[15,16,39,44]$, as well as from tropical regions, such as India, where no obvious epidemic season has been found [48].

To analyze the correlation between HBoV1 prevalence and meteorological conditions, multiple linear regression analysis was performed, with HBoV1 monthly prevalence as the dependent variable and mean temperature (or mean temperature in the preceding month), mean relative humidity, mean wind speed and sunshine duration as the independent variables (Table 2). Both regression models were established $(p<0.001)$ and the adjusted $R^{2}$ value $(0.373)$ of the temperature dorp 1 month model was greater than the adjusted $R^{2}$ value $(0.231)$ of the current monthly temperature model, indicating that the temperature dorp 1 month model had better explanatory power than the current monthly temperature model. Both of the models showed that the prevalence of $\mathrm{HBoV} 1$ was significantly correlated with temperature and relative humidity (Table 2). In detail, HBoV1 prevalence was positively correlated with temperature, that is consistent with previous reports $[47,49]$. Conversely, HBoV1 prevalence was negatively correlated with relative humidity, this was different from a previous report in Suzhou [47], which may be related to Guangzhou high humidity (mean monthly relative humidity was $77.2 \pm 7.3 \%$ ) (Fig. 3 ). It is common for pathogen prevalence to fluctuate over time because of a variety factors. In this study, HBoV1 prevalence was relatively low in 2013 to 2014. It might be partly related to the relatively higher mean relative humidity during this period (Fig. 3). Climate conditions may impact the survival and spread of respiratory viruses, however no significant linear relationship between HBoV1 infection and wind speed or sunshine duration were found in this study $(p>0.05)$ (Table 2).

Some limitations of this study should be noted. First, because our study mainly focused on HBoV1 circulation in hospitalized patients with ARI, HBoV1 in outpatients and the asymptomatic population were not included. Second, many factors can affect virus epidemics, meteorological data analysis alone may not serve as a final 
conclusive interpretation. Third, the study was only conducted in three hospitals and may not be representative of the overall population.

\section{Conclusions}

Our study has provided a better understanding of the epidemiology of HBoV1 in subtropical regions, specifically correlations with climate data; these data will be helpful for future control and prevention of HBoV1 infections.

\section{Acknowledgements}

We thank the study volunteers for their generous participation. We thank Yinghua Zhou, Haiping Huang, Jing Zhang and Jing Ma for their technical assistance.

\section{Funding}

This study was supported by National Natural Science Foundation of China (31500143); Guangzhou Science and Technology Program key projects (201803040004, 201704020225); The State Major Infectious Disease Research Program (2017ZX10103011-003, 2018ZX10102001); Natural Science Foundation of Guangdong Province (2016A030313572). The sponsors of the study had no role in the study design, data collection, data analysis, data interpretation, or writing of the report. The corresponding author had full access to all the data in the study and had final responsibility for the decision to submit for publication.

\section{Availability of data and materials}

The datasets used and/or analyzed during the current study are available from the corresponding author on reasonable request.

\section{Authors' contributions}

RZ, WKL and QL designed the study. WKL, QL, SYQ, DX, CL, XL and ZSL performed the pathogens testing. DHC, WPT and YC collected clinical data and screened the patients in this study. All authors participated in the data analysis. WKL, QL and RZ drafted the manuscript. All authors read and approved the final manuscript.

\section{Ethics approval and consent to participate}

The study was approved by The First Affiliated Hospital of Guangzhou Medical University Ethics Committee for research on human beings. The next of kin (>18 years old), caretakers, or guardians gave signed informed consent on behalf of the minors/children for participation in the study.

\section{Consent for publication}

Not applicable.

\section{Competing interests}

The authors declare that they have no competing interests.

\section{Publisher's Note}

Springer Nature remains neutral with regard to jurisdictional claims in published maps and institutional affiliations.

\section{Author details}

${ }^{1}$ State Key Laboratory of Respiratory Diseases, National Clinical Research Center for Respiratory Disease, The First Affiliated Hospital of Guangzhou Medical University, Guangzhou Institute of Respiratory Health, Guangzhou Medical University, Guangzhou, China. ${ }^{2}$ Central Laboratory, The First Affiliated Hospital of Guangdong Pharmaceutical University, Guangzhou, China. ${ }^{3}$ Sun Yat-Sen Memorial Hospital, Sun Yat-Sen University, Guangzhou, China.
Received: 28 November 2017 Accepted: 29 June 2018

Published online: 16 July 2018

\section{References}

1. Allander T, Tammi MT, Eriksson M, Bjerkner A, Tiveljung-Lindell A, Andersson B. Cloning of a human parvovirus by molecular screening of respiratory tract samples. Proc Natl Acad Sci U S A. 2005;102(36):12891-6.

2. Qiu J, Soderlund-Venermo M, Young NS. Human Parvoviruses. Clin Microbio Rev. 2017:30(1):43-113.

3. Bicer S, Giray T, Col D, Erdag GC, Vitrinel A, Gurol Y, Celik G, Kaspar C, Kucuk O. Virological and clinical characterizations of respiratory infections in hospitalized children. Ital J Pediatr. 2013;39:22

4. Moreno B, Abrego L, Carrera JP, Franco D, Gaitan M, Castillo J, Pascale JM, Arbiza J. Detection of human bocavirus type 1 infection in Panamanian children with respiratory illness. J Med Virol. 2016:88(3):389-94.

5. Li L, Zhu T, Chen ZR, Yan YD, He LP, Xu HM, Shao XJ, Yin F, Ji W. Detection of human bocavirus in nasopharyngeal aspirates versus in broncho-alveolar lavage fluids in children with lower respiratory tract infections. J Med Virol. 2016;88(2):211-5.

6. Garcia-Garcia ML, Calvo C, Pozo F, Perez-Brena P, Quevedo S, Bracamonte T, Casas I. Human bocavirus detection in nasopharyngeal aspirates of children without clinical symptoms of respiratory infection. Pediatr Infect Dis J. 2008; 27(4):358-60.

7. Martin ET, Taylor J, Kuypers J, Magaret A, Wald A, Zerr D, Englund JA. Detection of bocavirus in saliva of children with and without respiratory illness. J Clin Microbiol. 2009:47(12):4131-2.

8. Kantola K, Hedman L, Tanner L, Simell V, Makinen M, Partanen J, Sadeghi M, Veijola R, Knip M, llonen J, et al. B-cell responses to human Bocaviruses 1-4: new insights from a childhood follow-up study. PLoS One. 2015;10(9): e0139096.

9. Kahn JS, Kesebir D, Cotmore SF, D'Abramo A Jr, Cosby C, Weibel C, Tattersal $P$. Seroepidemiology of human bocavirus defined using recombinant viruslike particles. J Infect Dis. 2008;198(1):41-50.

10. Kantola K, Hedman L, Arthur J, Alibeto A, Delwart E, Jartti T, Ruuskanen O, Hedman K, Soderlund-Venermo M. Seroepidemiology of human bocaviruses 1-4. J Infect Dis. 2011;204(9):1403-12.

11. Li H, He M, Zeng P, Gao Z, Bian G, Yang C, Li W. The genomic and seroprevalence of human bocavirus in healthy Chinese plasma donors and plasma derivatives. Transfusion. 2015;55(1):154-63.

12. Guido M, Tumolo MR, Verri T, Romano A, Serio F, De Giorgi M, De Donno A, Bagordo F, Zizza A. Human bocavirus: current knowledge and future challenges. World J Gastroenterol. 2016;22(39):8684-97.

13. Pekcan S, Gokturk B, Uygun Kucukapan H, Arslan U, Findik D. Spontaneous pneumomediastinum as a complication in human bocavirus infection. Pediatr Int. 2014;56(5):793-5.

14. Jartti T, Hedman K, Jartti L, Ruuskanen O, Allander T, Soderlund-Venermo M. Human bocavirus-the first 5 years. Rev Med Virol. 2012;22(1):46-64.

15. Liu WK, Chen DH, Liu Q, Liang HX, Yang ZF, Oin S, Zhou R. Detection of human bocavirus from children and adults with acute respiratory tract illness in Guangzhou, southern China. BMC Infect Dis. 2011;11:345.

16. Ghietto LM, Majul D, Ferreyra Soaje P, Baumeister E, Avaro M, Insfran C, Mosca L, Camara A, Moreno LB, Adamo MP. Comorbidity and high viral load linked to clinical presentation of respiratory human bocavirus infection. Arch Virol. 2015;160(1):117-27.

17. Lu QB, Wo Y, Wang HY, Huang DD, Zhao J, Zhang XA, Zhang YY, Liu EM, Liu W, Cao WC. Epidemic and molecular evolution of human bocavirus in hospitalized children with acute respiratory tract infection. Eur J Clin Microbiol Infect Dis. 2015;34(1):75-81.

18. Arnott A, Vong S, Rith S, Naughtin M, Ly S, Guillard B, Deubel V, Buchy P. Human bocavirus amongst an all-ages population hospitalised with acute lower respiratory infections in Cambodia. Influenza Other Respir Viruses. 2013;7(2):201-10.

19. Flores CJ, Vizcaya AC, Araos BR, Montecinos PL, Godoy MP, ValienteEcheverria F, Perret PC, Valenzuela CP, Hirsch BT, Ferres GM. Human bocavirus in Chile: clinical characteristics and epidemiological profile in children with acute respiratory tract infections. Rev Chil Infectol. 2011; 28(6):504-11

20. Zhou L, Zheng S, Xiao Q, Ren L, Xie X, Luo J, Wang L, Huang A, Liu W, Liu E. Single detection of human bocavirus 1 with a high viral load in severe respiratory tract infections in previously healthy children. BMC Infect Dis. 2014;14:424. 
21. Ursic T, Steyer A, Kopriva S, Kalan G, Krivec U, Petrovec M. Human bocavirus as the cause of a life-threatening infection. J Clin Microbiol. 2011;49(3): 1179-81.

22. Beder LB, Hotomi M, Ogami M, Yamauchi K, Shimada J, Billal DS, Ishiguro N, Yamanaka N. Clinical and microbiological impact of human bocavirus on children with acute otitis media. Eur J Pediatr. 2009;168(11):1365-72.

23. Korner RW, Soderlund-Venermo M, van Koningsbruggen-Rietschel S, Kaiser R, Malecki M, Schildgen O. Severe human bocavirus infection, Germany. Emerg Infect Dis. 2011;17(12):2303-5.

24. Zhang DM, Ma MM, Wen WT, Zhu X, Xu L, He ZJ, He X, Wu JH, Hu YW, Zheng $Y$, et al. Clinical epidemiology and molecular profiling of human bocavirus in faecal samples from children with diarrhoea in Guangzhou, China. Epidemiol Infect. 2015;143(11):2315-29.

25. Allander T, Jartti T, Gupta S, Niesters HG, Lehtinen P, Osterback R, Vuorinen T, Waris M, Bjerkner A, Tiveljung-Lindell A, et al. Human bocavirus and acute wheezing in children. Clin Infect Dis. 2007:44(7):904-10

26. Karalar L, Lindner J, Schimanski S, Kertai M, Segerer H, Modrow S. Prevalence and clinical aspects of human bocavirus infection in children. Clin Microbiol Infect. 2010;16(6):633-9.

27. Pozo F, Garcia-Garcia ML, Calvo C, Cuesta I, Perez-Brena P, Casas I. High incidence of human bocavirus infection in children in Spain. J Clin Virol. 2007;40(3):224-8

28. Wang K, Wang W, Yan H, Ren P, Zhang J, Shen J, Deubel V. Correlation between bocavirus infection and humoral response, and co-infection with other respiratory viruses in children with acute respiratory infection. J Clin Virol. 2010;47(2):148-55.

29. Mori D, Ranawaka U, Yamada K, Rajindrajith S, Miya K, Perera HK, Matsumoto T, Dassanayake M, Mitui MT, Mori H, et al. Human bocavirus in patients with encephalitis, Sri Lanka, 2009-2010. Emerg Infect Dis. 2013; 19(11):1859-62.

30. Yu JM, Chen QQ, Hao YX, Yu T, Zeng SZ, Wu XB, Zhang B, Duan ZJ. Identification of human bocaviruses in the cerebrospinal fluid of children hospitalized with encephalitis in China. J Clin Virol. 2013;57(4):374-7.

31. Mitui MT, Tabib SM, Matsumoto T, Khanam W, Ahmed S, Mori D, Akhter N, Yamada K, Kabir L, Nishizono A, et al. Detection of human bocavirus in the cerebrospinal fluid of children with encephalitis. Clin Infect Dis. 2012;54(7): 964-7.

32. Hamza IA, Jurzik L, Wilhelm M, Uberla K. Detection and quantification of human bocavirus in river water. J Gen Virol. 2009;90(Pt 11):2634-7.

33. Rasanen S, Lappalainen S, Kaikkonen S, Hamalainen M, Salminen M, Vesikari T. Mixed viral infections causing acute gastroenteritis in children in a waterborne outbreak. Epidemiol Infect. 2010;138(9):1227-34.

34. Blinkova O, Rosario K, Li L, Kapoor A, Slikas B, Bernardin F, Breitbart M, Delwart $E$. Frequent detection of highly diverse variants of cardiovirus, cosavirus, bocavirus, and circovirus in sewage samples collected in the United States. J Clin Microbiol. 2009;47(11):3507-13.

35. Deng X, Yan Z, Luo Y, Xu J, Cheng F, Li Y, Engelhardt JF, Qiu J. In vitro modeling of human bocavirus 1 infection of polarized primary human airway epithelia. J Virol. 2013:87(7):4097-102.

36. Huang Q, Deng X, Yan Z, Cheng F, Luo Y, Shen W, Lei-Butters DC, Chen AY, Li $Y$, Tang $L$, et al. Establishment of a reverse genetics system for studying human bocavirus in human airway epithelia. PLoS Pathog. 2012;8:e1002899.

37. Deng X, Li Y, Qiu J. Human bocavirus 1 infects commercially available primary human airway epithelium cultures productively. J Virol Methods. 2014;195:112-9.

38. du Prel JB, Puppe W, Grondahl B, Knuf M, Weigl JA, Schaaff F, Schmitt HJ. Are meteorological parameters associated with acute respiratory tract infections? Clin Infect Dis. 2009;49(6):861-8.

39. Liu WK, Liu Q, Chen DH, Liang HX, Chen XK, Chen MX, Qiu SY, Yang ZY, Zhou R. Epidemiology of acute respiratory infections in children in Guangzhou: a three-year study. PLoS One. 2014;9(5):e96674.

40. Liu WK, Liu Q, Chen DH, Liang HX, Chen XK, Huang WB, Qin S, Yang ZF, Zhou R. Epidemiology and clinical presentation of the four human parainfluenza virus types. BMC Infect Dis. 2013;13:28.

41. Walker CL, Rudan I, Liu L, Nair H, Theodoratou E, Bhutta ZA, O'Brien KL, Campbell H, Black RE. Global burden of childhood pneumonia and diarrhoea. Lancet. 2013;381(9875):1405-16.

42. Luksic I, Kearns PK, Scott F, Rudan I, Campbell H, Nair H. Viral etiology of hospitalized acute lower respiratory infections in children under 5 years of age - a systematic review and meta-analysis. Croat Med J. 2013;54(2):122-34
43. Schlaberg R, Ampofo K, Tardif KD, Stockmann C, Simmon KE, Hymas W, Flygare S, Kennedy B, Blaschke A, Eilbeck K, et al. Human Bocavirus capsid messenger RNA detection in children with pneumonia. J Infect Dis. 2017; 216(6):688-96.

44. Martin ET, Kuypers J, McRoberts JP, Englund JA, Zerr DM. Human Bocavirus1 primary infection and shedding in infants. J Infect Dis. 2015;212(4):516-24.

45. Fox JD. Respiratory virus surveillance and outbreak investigation. J Clin Virol. 2007:40(Suppl 1):S24-30.

46. Tregoning JS, Schwarze J. Respiratory viral infections in infants: causes, clinical symptoms, virology, and immunology. Clin Microbiol Rev. 2010;23(1):74-98.

47. Chen ZR, Mize M, Wang YQ, Yan YD, Zhu CH, Wang Y, Ji W. Clinical and epidemiological profiles of lower respiratory tract infection in hospitalized children due to human bocavirus in a subtropical area of China. J Med Virol. 2014;86(12):2154-62.

48. Bharaj P, Sullender WM, Kabra SK, Broor S. Human bocavirus infection in children with acute respiratory tract infection in India. J Med Virol. 2010; 82(5):812-6.

49. do Amaral de Leon C, Amantea SL, Pilger DA, Cantarelli V. Clinical and epidemiologic profile of lower respiratory tract infections associated with human bocavirus. Pediatr Pulmonol. 2013:48(11):1112-8.

\section{Ready to submit your research? Choose BMC and benefit from:}

- fast, convenient online submission

- thorough peer review by experienced researchers in your field

- rapid publication on acceptance

- support for research data, including large and complex data types

- gold Open Access which fosters wider collaboration and increased citations

- maximum visibility for your research: over $100 \mathrm{M}$ website views per year

At BMC, research is always in progress.

Learn more biomedcentral.com/submissions 